\title{
Erratum to: Effect of insertion route on risk of central line-associated bloodstream infection in critically ill patients
}

N. Hassan, A. Hammodi, R. Alhubail', Ali Alazem and N. Rayyan

\section{Erratum}

After publication of our recent Poster presentation [1], we noticed that three authors were inadvertently omitted as co-authors. The author list is now complete and reads follows: N. Hassan, A. Hammodi, R. Alhubail*, Ali Alazem, N. Rayyan.

Published online: 04 September 2015

\section{Reference}

1. Hassan N, Hammodi A, Alhubail R, Ali Alazem, Rayyan N. Effect of insertion route on risk of central line-associated bloodstream infection in critically ill patients. Crit Care. 2015;19:76.

* Correspondence: Rasheed.Hubail@kfsh.med.sa

ICU department, King Fahad Specialist Hospital-Dammam, 6830 Ammar Bin Thabit St, Al Muraikabat, 32253-3202 Dammam, Saudi Arabia
Submit your next manuscript to BioMed Central and take full advantage of:

- Convenient online submission

- Thorough peer review

- No space constraints or color figure charges

- Immediate publication on acceptance

- Inclusion in PubMed, CAS, Scopus and Google Scholar

- Research which is freely available for redistribution

Submit your manuscript at www.biomedcentral.com/submit

\section{Biomed Central}

